\begin{tabular}{|c|c|c|}
\hline Beitr. Ent. & Keltern & ISSN 0005-805X \\
\hline $\mathbf{6 1}(2011) 1$ & S. $223-238$ & 16.05 .2011 \\
\hline
\end{tabular}

\title{
Characterization of leaf-rollers attacking forest and fruit trees in Azerbaijan
}

\section{(Lepidoptera: Tortricidae)}

With 2 tables, 1 map and 1 figure

\section{Sheyda Maharramova}

\section{Summary}

Characterization of the leaf-roller moths (Tortricidae) attacking forest and fruit trees in the North (ShekiZagatala), East (Baku-Absheron), and South (Lenkoran-Astara) regions of Azerbaijan was conducted over the decade 1994-2004. Sixteen species of leaf-rollers representing 14 genera were found to be widespread throughout the regions - 9 species of Tortricinae and 7 species of Olethreutinae. Four species, Ptycholoma lecheana (L.), Cacoecimorpha pronubana HüBner, Eudemis profundana (Denis \& SCHIFFermüller), and Epinotia demarniana (FISCH.), are newly recorded for Azerbaijan. Tortrix viridana L. represented $46.0 \%$ of the total number of specimens, Archips rosanus L. $28.0 \%$, and Archips xylosteanus L. $20.2 \%$.

\section{Zusammenfassung}

In der Dekade 1994-2004 wurden im Norden (Sheki-Zagatala), Osten (Baku-Absheron) und Süden (Lenkoran-Astara) Aserbaidschans an Forst- und Obstbäumen schädigende Wickler untersucht. Dabei zeigte sich, dass 16 Wicklerarten aus 14 Gattungen (9 Tortricinae, 7 Olethreutinae) in der Region weit verbreitet sind. Vier weitere Arten, Ptycholoma lecheana (L.), Cacoecimorpha pronubana HüBnER, Eudemis profundana (Denis \& SChiffermüller) und Epinotia demarniana (FIsch.), wurden erstmals in Aserbaidschan gefunden. In den Proben hatten Exemplare von Tortrix viridana L. einen Anteil von 46.0 \%, Archips rosanus L. von $28.0 \%$ und Archips xylosteanus L. von $20.2 \%$.

\section{Key words}

Food plants, pest species, leaf-roller, caterpillar, pupa, imago.

\section{Introduction}

Tortricidae are one of the largest families of Microlepidoptera, with more than 9,000 described species (BROwn 2005) distributed worldwide. Information on the tortricids of Azerbaijan has been presented by Bogachev (1951), Akhundova-Tuayeva (1960), Abdullayeva (1988, 1990), and Maharramova $(2003,2006,2008)$, with over 200 species of leaf-rollers now recorded from the country (AbDullaYeVA, 1990).

Leaf rollers are primarily polyphagous and oligophagous. The common name "leaf-rollers" is derived from the fact that the larvae of many species roll the edge of the foliage on which they feed, creating a shelter that may protect them from predators such as birds. This leaf-rolling habit causes serious damage to a variety of forest and fruit trees and ornamental and other plants. Many pest species can be identified by the shape and configuration of the leaf shelter. 
The aim of the paper is to present an analysis of the species composition, host associations and yearly distribution of the leaf-rollers in several regions of Azerbaijan. Our object is to determine the host plants of Tortricidae. So we have not included the Tortricidae with unknown host plants.

Characterization of the leaf-roller moths (Tortricidae) attacking forest and fruit trees in the North (Sheki-Zagatala), East (Baku-Absheron), and South (Lenkoran-Astara) regions of Azerbaijan was conducted in 1994-2004. Sixteen species of leaf rollers representing 14 genera were found to be widespread throughout the regions - 9 species of Tortricinae and 7 species of Olethreutinae. Tortrix viridana L. represented $46.0 \%$ of the total specimens, Archips rosanus L. $28.0 \%$, and Archips xylosteanus L. $20.2 \%$; Archips crataeganus (Hüв), Ptycholoma lecheana (L.) and Aleimma loeflingiana (L.) each represented less than $1 \%$ of the specimens collected. The purpose of this paper is to detail the results of this survey.

\section{Material and methods}

Field work was conducted from 1994 to 2004 from April to September in the North (ShekiZagatala - 1995), East (Baku-Absheron - 1995-1997, 1999-2000, 2004) and South (Lenkoran - 1994-1997, 2001, 2003-2004; Astara - 1994-1998; Masalli - 1995-1996, 1998) regions of Azerbaijan. Forests, orchards, gardens, and roadsides were investigated within the research areas; Hirkan National Park also was sampled. The paper includes the leaf-rollers found on the host plants (trees and bushes only) in larval or pupal stage. Collected larvae and pupae were kept in the laboratory until imagines hatched. Species determination was done according to these imagines. Species were collected in nature in the larval and pupal stage.

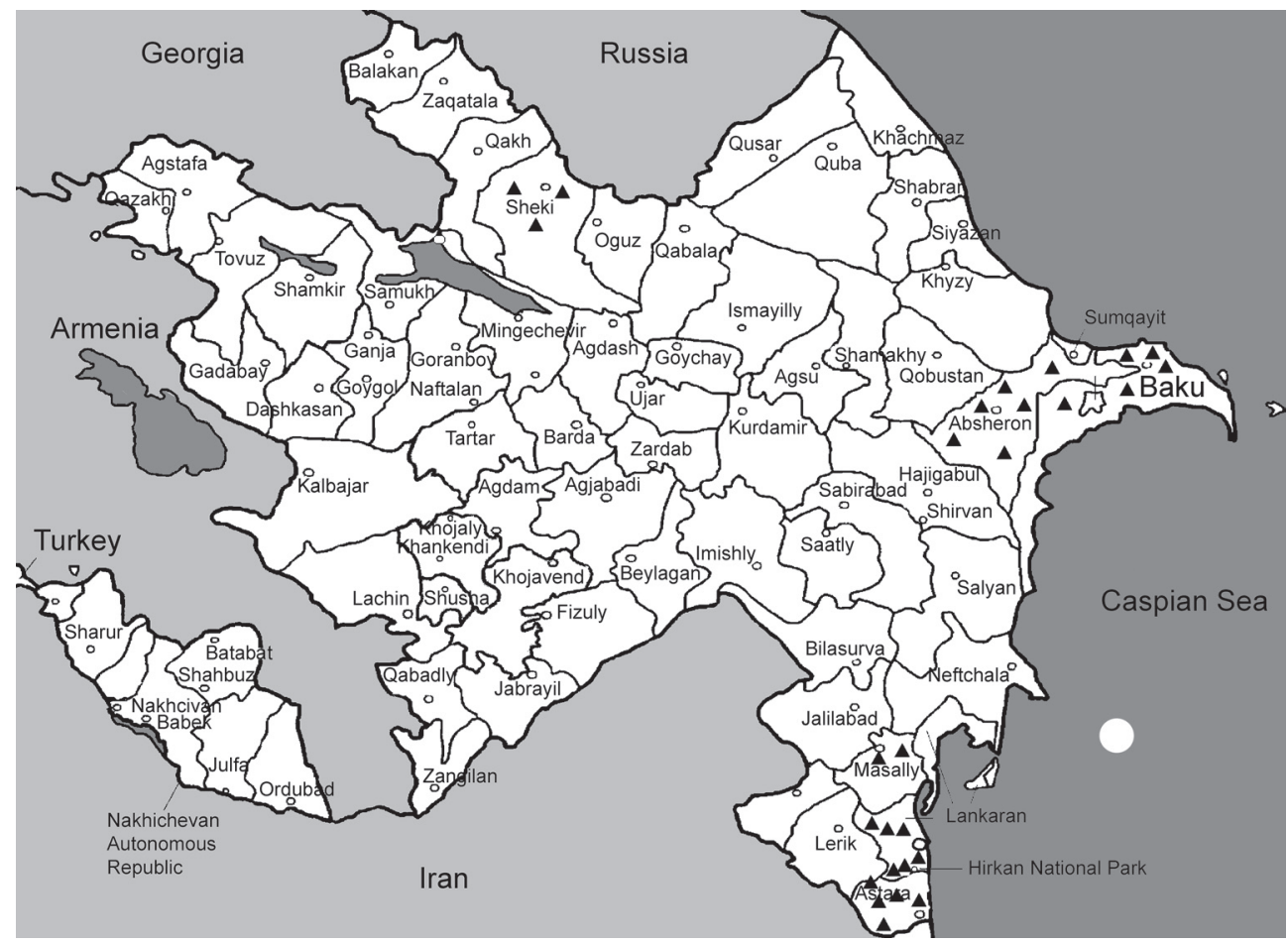

Fig. 1: Map of Azerbaijan: $\circ$ designations;

- material collected area. 
Each larva picked from the host plant was kept in a separate jar in the laboratory and fed on host plant leaves. Development of each specimen was observed up to imago stage (FAsulati, 1971). Laboratory work was conducted at the Institute of Zoology of the National Academy of Sciences of Azerbaijan. All specimens are deposited in that institution.

\section{Study sites:}

Forests in the Sheki-Zagatala region of Azerbaijan (Fig. 1) are characterized by a predominance of fruit trees, forest trees, and shrubs. The Baku and Absheron peninsulas in eastern Azerbaijan are characterized by a variety of endemic plants but also by invasives introduced from different countries and other regions of Azerbaijan. The southern regions of Azerbaijan (Lenkoran, Astara, and Masalli) are characterized by 36 species of endemic and relic plants of the tertiary era and 40 species of plants dating from of quaternary period.

Results

Subfamily Tortricinae

Tribe Archipini

Genus Pandemis HüBner, 1825

Pandemis cerasana (HÜBNER, 1786)

\section{Specimens examined:}

Azerbaijan: Astara District: Tengerud vil., 19 May 1995, Malus sp., 2 ㅇ 우 ; Tengerud vil., 19 May 1995, Malus sp., 2 o o`; Serek vil., 19 May 1995, Malus sp., 1 + ; Serek vil., 20 May 1995, Malus sp., 1 ơ; Serek vil., 24 May 1995, Crataegus sp., 1 \% ; Astara, 25 May 1995, Crataegus sp., 1 ㅇ.

Larvae and pupae of this species were discovered in the field. The larvae damage leaves and fruit near leaves of the host; the primary host is Malus sp. (Table 2). Caterpillars fold the edge of the leaf and bend it toward the mid-vein or spin leaves together with silk. Caterpillars skeletonize leaves and occasionally damage the fruit pedicel which causes the fruit to decay. Caterpillars pupate in the same place as they feed. Females lay eggs in groups of 20-100 on the upper side of the leaf.

\section{Genus Archips HüBNER, 1822}

Archips rosanus (LinNaEus, 1758)

\section{Specimens examined:}

Azerbaijan: Lenkeran District, 20 September 1994, Quercus castaneifolia, 1 \% . Sheki District, Dodu v., 22 April 1995, Malus sp., 10 우 ㅇ, 5 o $^{-1}$; Sheki District, 22 April 1995, Malus sp., 1 o $^{\top}$; 23 April 1995, Prunus domestica, 1 ; 11 May 1995, Armeniaca vulgaris, 1 \% ; Astara District, Archivan v., 14 May 1995, Cydonia sp., 2 ㅇ ㅇ ; Astara District, 15 May 1995, Malus sp., 1 ơ; Sheki District, Dodu v., 16 May 1995, Malus sp., 1 ơ $^{*}$ Astara District, Archivan v., 17 May 1995, Cydonia sp., 3 ơ ơ; 20 May 1995, Cydonia sp., 1 ; 20 May 1995, Malus sp., 1 \%; Sheki District, 21 May 1995, Malus sp., 1 o $^{\star}$; Astara District, Serek v., 24 May 1995, Crataegus sp., 3 ㅇ 우, 5 o o o $^{*}$ Sheki District, 24 May 1995, A. vulgaris, 2 ㅇ ; Baku city, 24 May 1995, A. vulgaris, 9 ㅇ ; 24 May 1995, Malus sp., 1 o $^{\top}$; 29 May 1995, Malus sp., 3 우 ㅇ, 10 o $^{\top}$ o $^{*}$; Absheron penin., Merdekan sett., 
14 May 1996, Cydonia sp., 1 ; Baku city, 16 May 1996, A. vulgaris, 12 ㅇ , 10 ơ ơ; 30 July 1996, Cydonia sp., 1 o $^{*} 13$ August 1996, Ulmus suberosa, 1 o $^{*}$; Astara District, Arcivan v., 14 May 1997, Q. castaneifolia, 1 ; 14 May 1997, Malus sp., 2 ㅇ ; Baku city, 10 June 1997, Amorpha fruticosa,

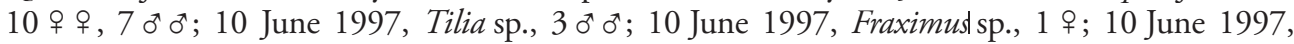
Colutea sp., 1 \%; Astara District, Serek v., 10 June 1997, Q. castaneifolia, 1 + ; Baku city: 11 June 1997, Maclura aurantica, 1 \%; 11 June 1997, Crataegus sp., 1 ơ 12 June 1997, Colutea sp., 1 ; 12 June 1997, Tilia sp., 1 o; 12 June 1997, Ligustrum sp., 6 우; 17 June 1997, A. fruticosa, 1 ; 18 June 1997, U. suberosa, 1 ơ; 23 June 1997, Punica granatum, 1 ; 15 June 1999, A. vulgaris, 1 ; : Lenkeran District, Hirkan National Park: 7 May 2001, P. persica, $10^{*} ; 7$ May 2001, Alnus barbata, 1 \%; Lenkeran District, Khanbulan area, 10 May 2001, Salix kusnetzowii, 1 ; 10 May 2001, Rubus sp., 2 o $^{\star}$; 11 May 2001, Rubus sp., 2 o $^{\star}$; 11 May 2001, S. kusnetzowii, 2 ㅇ ㅇ; Lenkeran District, Hirkan National Park, 15 May 2001, Gleditsia caspia, 2 o $^{\top}$ o $^{*}$; Lenkeran District, Khanbulan area, 15 May 2001, S. kusnetzowii, 2 ㅇ ㅇ ; Lenkeran District, Hirkan National Park: 15 May 2001, A. barbata, $10^{\star}$; 15 May 2001, Q. castaneifolia, 1 \%; Lenkeran District, Khanbulan area, 16 May 2001, Q. castaneifolia, 2 우 ㅇ 16 May 2001, S. kusnetzowii, 2 ㅇ 우, 1 ơ; Lenkeran District, Hirkan National Park, 16 May 2001, Parrotia persica, 1 ơ; 16 May 2001, Carpinus caucasica, 1 ơ; Lenkeran District, Khanbulan area: 16 May 2001, Rubus sp., 1 +; 17 May 2001, P. persica, 1 ; 17 May 2001, Rubus sp., $10^{\star}$; Lenkeran District, Hirkan National Park, 18 May 2001, Q. castaneifolia, $70^{\star} 0^{\star}$, 7 우 ㅇ 18 May 2001, Zelkova carpinifolia, 1 o $^{-}$; Lenkeran District, Khanbulan area, 18 May 2001, Rubus sp., 1 + ; Lenkeran District, Hirkan National Park, 21 May 2001, P. persica, 1 ơ; 23 May 2001, Z. carpinifolia, 1 ; 24 May 2001, Q. castaneifolia, 10 \% ; 29 May 2001, P. persica, 1 \%;

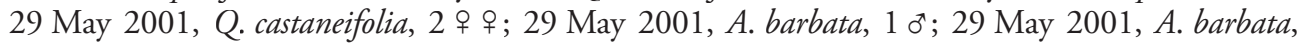
1 ; : Lenkeran District, Hirkan National Park, Druzavel area, 29 May 2001, Robina pseudoacacia, 1 \%; Lenkeran District, Hirkan National Park, 29 May 2001, Q. castaneifolia, 1 ; 29 May 2001, S. kusnetzowii, 2 o $^{\top}$; 29 May 2001, Q. castaneifolia, 1 \% 29 May 2001, Gleditsia caspia, 2 \% + ; 29 May 2001, Mespilus sp., $2 \sigma^{\top} \sigma^{\star}$; Lenkeran District, Xanbulan area, 29 May 2001, Acer hyrcanum, 1 ㅇ ; Lenkeran District, Hirkan National Park, Druzavel area, 29 May 2001, Robina pseudoacacia, 1 ㅇ, 1 ơ; Lenkeran District, Hirkan National Park, 30 May 2001, Q. castaneifolia, 3 ㅇ ㅇ, $10^{\top}$; Lenkeran District, Khanbulan area, 30 May 2001, Q. castaneifolia, 1 i 1 ơ $^{\text {; }}$ Lenkeran District, Hirkan National Park: 30 May 2001, Q. castaneifolia, 3 ơ ơ; 30 May 2001, C. caucasica, 2 ㅇ ; 1 June 2001, $P$. persica, 4 9 9 ; 01 June 2001, A. barbata, $3 o^{*} o^{*}$; Lenkeran District, Khanbulan area, 1 June 2001, P.persica, 2 우, $30^{\star} \sigma^{\star} ; 1$ June 2001, P. persica, $10^{\star}$; 1 June 2001, Q. castaneifolia, 4 우 우 $1 \sigma^{\star}$; Lenkeran District, Hirkan National Park: 5 June 2001, Q. castaneifolia, 1 o $^{\star}$; 5 June 2001, P. persica, 1 \%; 05 June 2001, Z. carpinifolia, 1 \% ; June 2001, P. persica, $10^{*} ; 5$ June 2001, Q. castaneifolia, 1 \%; 29 April 2002, Z. carpinifolia, $10^{\top}$; 25 May 2002, P. persica, 1 ơ; Absheron penins., Merdekan sett., 24 June 2003, Q. castaneifolia, 1 \% ; Lenkeran District, Azfilial area, 24 May 2004, Planatus digitifolia, 2 ㅜ ; Lenkeran District, Hirkan National Park, 25 May 2004, Ligustrum sp., 2 우; + Baku city, 31 May 2004, Fraxinus sp., 1 ㅇ, 1 ơ; Lenkeran District, 31 May 2004, Q. castaneifolia, 2 ㅇ ㅇ , $10^{\star}$; 31 May 2004, P. persica, 1 ㅇ, 1 o $^{\star}$; Lenkeran District, Khanbulan area, 1 June 2004, Rubus sp., 10 우 우 $10^{\star}$; Baku city, 7 June 2004, Fraxinus sp., 3 ㅇ 9 ; 8 June 2004, Fraximus sp., $10^{\circ}$.

We discovered caterpillars and pupae in the field. Larvae of $A$. rosanus roll one to several leaves and join them by silk. When the shelter includes one leaf, it is rolled from the edge towards the mid-vein. Larvae feed on the parenchyma, leaving the veins. A. rosanus damages primarily terminal buds and shoots, but larvae attack buds, flowers, leaves, and fruits. Twenty-six plant species were recorded as hosts, including all deciduous trees, forest plants, ornamental plants, shrubs, subtropical plants, and berries, with Quercus castaneifolia, Malus sp., and Armeniaca vulgaris as the main food plants. 
Our observations indicate that $A$. rosanus is univoltine. Each egg mass contains up to 60 eggs; the average productivity of a female is 250 eggs. This species overwinters in the egg stage. Bursting of the apple tree buds serves as a phenological signal for the pest to break winter diapause (Maharramova, 2003).

\section{Archips crataeganus (HÜBNER, [1799])}

Specimens examined:

Azerbaijan: Lenkeran District, 1 June 2001, Rubus sp., 1 ㅇ․

Rather than rolling the leaves of the host, Archips crataeganus joins the axial leaves of a branch with silk creating a nest within which it feeds.

\section{Archips xylosteanus (LinNaEus, 1758)}

\section{Specimens examined:}

Azerbaijan: Sheki District, Dodu v., 22 April 1995, Malus sp., 1 \%; Baku city, 16 May 1996, Armeniaca vulgaris, $10^{\top}$; Lenkeran District, Hirkan National Park, 7 May 2001, Q. castaneifolia, 1 우 1 ơ⿱$^{\star}$; Lenkeran District, Khanbulan area, 8 May 2001, Alnus subcordata, 1 ; ; Lenkeran District,

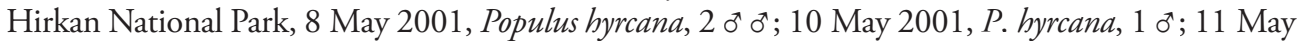

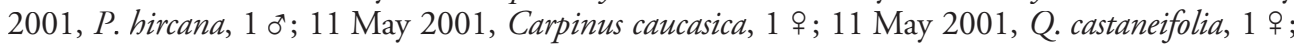
15 May 2001, Q. castaneifolia, 1 \% 15 May 2001, C. caucasica, 2 o $^{\top}$; 15 May 2001, P. hircana, 1 ; Lenkeran District, Khanbulan, 15 May 2001, Q. castaneifolia, 1 + ; Lenkeran District, Hirkan National Park: 16 May 2001, Parrotia persica, 1 \%; 16 May 2001, C. caucasica, 1 \%; Lenkeran District, Khanbulan area, 16 May 2001, Q. castaneifolia, $20^{\star} o^{\star}$; 16 May 2001, P. persica, 2 ㅇ ㅇ ; Lenkeran District, Hirkan National Park, 16 May 2001, Mespilus sp., 1 \% Lenkeran District, Khanbulan area, 17 May 2001, P.persica, $10^{\star}$; Lenkeran District, Hirkan National Park: 18 May 2001, Z. carpinifolia, 5 우 ㅇ , 1 o $^{\star}$; 18 May 2001, Q. castaneifolia, 14 우 ㅇ; 18 May 2001, P. persica, 1 ㅇ; 29 May 2001, Mespilus sp., 3 o o ; 29 May 2001, Populus hyrcana, 1 \%; 29 May 2001, Z. carpinifolia, 5 우; 29 May 2001, Q. castaneifolia, 3 ㅇ ㅇ; 29 May 2001, C. caucasica, 3 ơ ơ; Lenkeran District, Khanbulan area: 29 May 2001, P. persica, 1 +; 30 May 2001, Q. castaneifolia, 9 $~+, 9 o^{\star} o^{\star} ; 30$ May 2001, C. caucasica, 3 ㅇ ㅇ; 30 May 2001, Q. castaneifolia, 2 ㅇ ㅇ, 3 o $^{\star \top}$; Lenkeran District, Hirkan National Park, 1 June 2001, Q. castaneifolia, 31 ㅇ $+11 o^{-1} \sigma^{*}$; Lenkeran District, Khanbulan area, 1 June 2001, Q. castaneifolia, 1 \% ; Lenkeran District, Hirkan National Park, 1 June 2001, P. persica,

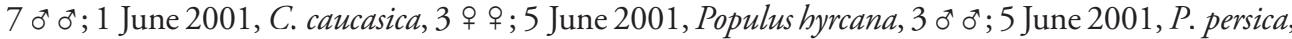
1 ; 27 April 2002, Q. castaneifolia, 3 ㅇ ㅇ; 29 April 2002, P. persica, 10 ㅇ 우, 3 o o o $^{\star} ; 29$ April 2002, Q. castaneifolia, 13 우 ㅇ, 4 o $^{*} \sigma^{*} ; 29$ April 2002, Z. carpinifolia, 2 ㅇ ㅇ; 1 May 2002, Q. castaneifolia, 1 ơ $^{\star} 3$ May 2004, Q. castaneifolia, 3 o $^{\star}$; 25 May 2004, Q. castaneifolia, 1 \%; Lenkeran District, Khanbulan area, 31 May 2004, Q. castaneifolia, $40^{\star} 0^{\star}$; 1 June 2004, Rubus sp., 1 ㅇ.

Caterpillars and pupae of Archips xylosteanus were collected in nature. This species is a defoliator of a wide range of broadleaf trees. Larvae are omnivorous and are known to damage orchard, ornamental, and forest trees. Females lay eggs in groups of 2-100 eggs on the trunk of the tree or on branches near the ground. The phenological signal for caterpillar hatching is opening of the apple tree buds. Caterpillars roll the leaf beginning from the top of the leaf along its width. We documented larval damage on more than 10 species of plants, but especially Q. castaneifolia, $P$. persica, and $Z$. carpinifolia (Table 2). A. xylosteanus was recorded throughout the study area and survey period; however, it was most numerous in 2001-2002 in Lenkoran. 


\section{Genus Ptycholoma Stephens, 1929}

Ptycholoma lecheana (Linnaeus, 1758)

Specimens examined:

Azerbaijan: Absheron penins., Merdekan settl., 22 May 2001, Q. castaneifolia, 1 ㅇ.

Early instars skeletonize leaves; later instars damage buds, flowers, and newly emerged leaves. Larvae join several new leaves by silk and feed inside.

\section{Genus Cacoecimorpha OBRazTsov, 1954 \\ Cacoecimorpha pronubana HÜBNER, 1800}

Specimens examined:

Azerbaijan: Absheron penin., Merdekan settl., 6 June 1997, Laurus sp., 1 क ; Lenkeran District, Hirkan National Park, 27 June 2003, Ligustrum sp., 1 ơ.

Larvae were collected in nature. Caterpillars spin together 2-3 leaves with silk and eat the parenchyma tissue inside.

\section{Tribe Tortricini}

Genus Aleimma HüBNER, [1825]

Aleimma loeflingiana (LINNAEUS, 1758)

Specimens examined:

Azerbaijan: Lenkeran District, 24 June 2003, Q. castaneifolia, 1 ㅇ․

The caterpillar wraps leaves from the main rib to the lower face obliquely and ties them with silk.

\section{Genus Tortrix Linnaeus, 1758}

Tortrix viridana LINNAEUS, 1758

\section{Specimens examined:}

Azerbaijan: Lenkeran District, 20 April 1994, Q. castaneifolia, 1 \% ; Lenkeran District, Hirkan National Park: 30 April 1994, Q. castaneifolia, 1 \&; 5 May 1994, Q. castaneifolia, 1 \%; Lenkeran District, Khanbulan area, 20 April 1994, Q. castaneifolia, 1 , 2 o $^{\top} o^{*}$; Lenkeran District: 10 May

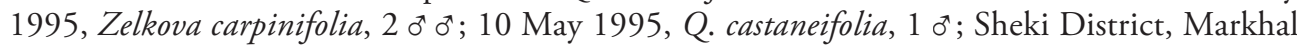
area, Quercus sp., 15 May 1995, 1 \% ; Astara District: 15 May 1995, Q. castaneifolia, 1 ; 17 May 1995, Q. castaneifolia, 1 o$^{\star}$; Astara District, Q. castaneifolia, Serek v., 18 May 1995, Astara District, Q. castaneifolia, 1 ơ; Astara District, Serek v., 19 May 1995, Ulmus suberosa, 1 \% ; 19 May 1995, 10 우 ㅇ, 2 o o ; 19 May 1995, Carpinus caucasica, 1 ; 19 May 1995, P. persica, 1 ơ $^{*}$ Astara District, Tengerud v., 19 May 1995, Q. castaneifolia, 9 q + ; 19 May 1995, Tilia sp., 3 o $^{\star}$; Astara District, 19 May 1995, Q. castaneifolia, $20^{\star} o^{\star}$; Masally District, 20 May 1995,

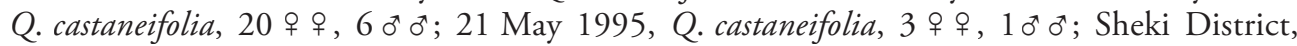
Markhal area, 24 May 1995, Quercus sp., 1 o'; Masally District, 24 May 1995, Q. castaneifolia,

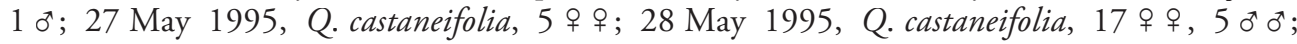
24 April 1996, Q. castaneifolia, 1 \% ; Lenkeran District, Hirkan National Park: 2 May 1996, 
Q. castaneifolia, $10^{\star}$; 5 May 1996, Q. castaneifolia, $10^{\text {* }}$; Lenkeran District: 15 May 1996, Q. castaneifolia, 1 \% 15 June 1996, Q. castaneifolia, 1 \% ; Astara District, Archivan v., 14 May 1997, Q. castaneifolia, 6 우 9 , 2 ๙ $^{\star}$; Astara District, 16 May 1997, Q. castaneifolia, 1 ㅇ ; Astara District, Tengerud v., 19 May 1997, Q. castaneifolia, 1 o'; Baku city, 18 June 1997, Ulmus suberosa, 1 o $^{\text {; }}$ Lenkeran District: 22 June 1997, Q. castaneifolia, 1 ơ $^{\text {; }} 27$ June 1997, Z. carpinifolia, 1 \%; Masally District, 22 May 1998, Q. castaneifolia, 1 \% ; Lenkeran District, Hirkan National Park: 29 April 2001, Populus hyrcana, 1 \% 02 May 2001, Q. castaneifolia, 1 o $^{\star} ; 3$ May 2001, Zelkova carpinifolia, 1 đ’; 4 May 2001, Cydonia sp., 1 ㅇ; 4 May 2001, Q. castaneifolia, 2 ㅇ ㅇ, 3 o $^{\star}$; 4 May 2001, Z. carpinifolia, 5 o $^{\star}$; 4 May 2001, Populus hyrcana, 1 \%; 4 May 2001,

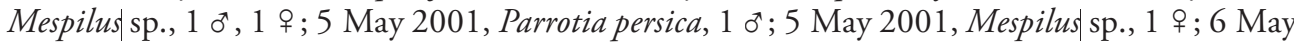
2001, Cydonia sp., 1 ; ; 6 May 2001, Q. castaneifolia, 4 ㅇ ㅇ, 6 o $^{\top}$ o $^{*} 6$ May 2001, Z. carpinifolia, 5 우 우, 2 ๙ $^{\top} o^{\star}$; 6 May 2001, P. hyrcana, 4 ㅇ ㅇ; 6 May 2001, Alnus barbata, 3 o $^{\top} o^{\star} ; 6$ May 2001, Mespilus sp., 2 우 우, 1 ơ; 6 May 2001, Crataegus sp., 4 우 ㅇ, 7 May 2001, P. persica, 1 ơ; 7 May 2001, Q. castaneifolia, 10 우, $20^{\star} o^{\star} ; 8$ May 2001, Q. castaneifolia, 6 우 ㅇ, $200^{\star} o^{\star} ; 8$ May 2001, U. suberosa, 10 우 우, 21 o $^{\star} 0^{\star} ; 8$ May 2001, Carpinus caucasica, 2 우 우, 3 o $^{\star}$ o $^{\star} ; 8$ May 2001,

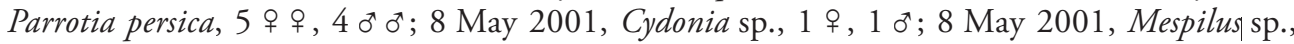
1 ; 9 May 2001, Q. castaneifolia, 2 우, $2 \sigma^{\star} o^{\star}$; Lenkeran District, Khanbulan area, 9 May 2001, P. persica, 1 \% ; Lenkeran District, Hirkan National Park, 9 May 2001, Z. carpinifolia, 2 ơ $^{\star}$; 9 May 2001, Mespilus sp., 1 ; 10 May 2001, Zelkova carpinifolia, 1 \%; 10 May 2001, Q. castaneifolia, 4 우; 10 May 2001, P. persica, $30^{\star} o^{\star} ; 10$ May 2001, Z. carpinifolia, 2 ㅇ ㅇ; Lenkeran District, Khanbulan area, 10 May 2001, P. persica, $20^{\top} o^{\star}$; Lenkeran District, Hirkan National Park: 10 May 2001, Crataegus sp., 1 ; 11 May 2001, Z. carpinifolia, 2 ㅇ ; 11 May 2001, Mespilus sp., 1 o; 11 May 2001, Ulmus suberosa, 1 ; 11 May 2001, Q. castaneifolia, 2 우 ㅇ; 14 May 2001, Q. castaneifolia, 1 ơ; 15 May 2001, P. persica, 2 ㅇ 우, 1 ơ; 15 May 2001, Q. castaneifolia, 1 ; 15 May 2001, U. suberosa, 1 \% 15 May 2001, Cydonia sp., 1 ơ; Lenkeran District, Khanbulan area, 15 May 2001, P. persica, 2 ㅇ ㅇ ; Lenkeran District, Hirkan National Park, 16 May 2001, Cydonia sp., 1 ơ⿱ $^{\star}$ : Lenkeran District, Khanbulan area, 16 May 2001, P. persica, 2 우; 16 May 2001, Q. castaneifolia, $20^{7} o^{7}$; Lenkeran District, Hirkan National Park: 16 May 2001, Z. carpinifolia, 1 , 1 ơ; 16 May 2001, Mespilus sp., 1 \% 16 May 2001, Q. castaneifolia, 1 ơ $^{\star} 17$ May 2001, Crataegus sp., 1 o'; 17 May 2001, Carpinis caucasica, 1 \%; 17 May 2001, P. persica, 1 + 17 May 2001, Cydonia sp., 1 o $^{*}$; Lenkeran District, Khanbulan area, 17 May 2001, P. persica, 2 ㅇ +18 May 2001, P. persica, 1 o $^{\star}$; Lenkeran District, Hirkan National Park: 18 May 2001, Carpinis caucasica, 1 o`; 18 May 2001, Crataegus sp., 1 ㅇ 18 May 2001, Zelkova carpinifolia, 3 우 P. persica, 8 우, $10^{\star} ; 21$ May 2001, Cydonia sp., 1 ㅇ, 1 o $^{\star}$; 21 May 2001, Ulmus suberosa, 8 우; 22 May 2001, Carpinus caucasica, 4 ㅇ ㅇ; 22 May 2001, Q. castaneifolia, 9 ㅇ 우, $20^{\top} o^{\star}$; 24 May 2001, Q. castaneifolia, 7 i +3 o $^{\top}$; 29 May 2001, Q. castaneifolia, 7 i ; 29 May 2001, C'rataegus sp., 1 +, 2 o $^{\star} ; 29$ May 2001, Mespilus sp., 1 + ; 30 May 2001, Q. castaneifolia,

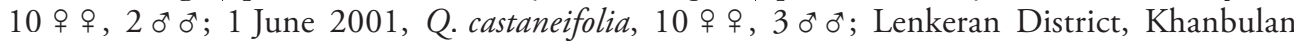
area, 1 June 2001, P. persica, 2 우; Lenkeran District, Hirkan National Park: 1 June 2001, U. suberosa, 1 ; 5 June 2001, U. suberosa, 6 + + ; 1 May 2002, Q. castaneifolia, 1 o* 3 May 2004, Z. carpinifolia, $2 \sigma^{\star} \sigma^{\star}$; 3 May 2004, Q. castaneifolia, 3 우 ㅇ, $40^{\star} \sigma^{\star} ; 18$ May 2004, Q. castaneifolia, 1 + , 1 o'; 19 May 2004, Q. castaneifolia, $10^{*}$.

We collected caterpillars, pupae, and adults of Tortrix viridana. This species overwinters as an egg, which remains dormant until the host leaf buds begin to open in mid-March or early April of the following year. The young caterpillars feed on tender leaves until late April or early May. The fully grown caterpillars eat the leaves entirely. Pupation takes place inside the rolled leaves. Moths begin to emerge about the first of May. Peak flight occurs about 10-15 May. Females lay 
up to 40-120 eggs, depending on host plant. Females begin to lay egg mass containing 2 eggs on leaves or twigs of trees completing the one-year life cycle. The literature provides somewhat varying information on host plants of T. viridana. Some authors (e.g., Lozovoy, 1965; Abdullayeva, 1990; RaYXXolf-Rim, 2002) considered it to be monophagous, feeding on only one or two species of oak; other authors consider the species to be oligophagous, feeding on several species of oak (Zerova et al., 1989). However, according to Voronsov (1967), the young caterpillars have been recorded from oak, lime, and poplar. We documented $T$. viridana on 12 different tree species in Azerbaijan (Table 2); Q. castaneifolia, Z. carpinifolia, $U$. suberosa, and $P$. persica are attacked most often by $T$. viridana (Maharramova, 2008).

Larval survival of this species is $58 \%$ on Q. castaneifolia, $59 \%$ on Z. carpinifolia, $82 \%$ on U. suberosa. Female productivity varied depending on host. It was 43.5 on Quercus, 46 on $P$. persica, 49.6 on Z. carpinifolia, 49.6 on C. caucasica, and 54 on U. suberosa.

\section{Genus Croesia HüBneR, [1825] \\ Croesia forskaleana (LINNAEUs, 1758)}

Specimens examined:

Azerbaijan: Lenkeran District, Khanbulan area, 29 May 2001, Acer hyrcanum, 5 ㅇ 우, $80^{\star \top} 0^{\star}$.

Overwintering caterpillars damage the first flowers of the host and then roll the leaves. Adults fly from May to August. Caterpillars were collected in nature.

\section{Subfamily Olethreutinae}

\section{Tribe Olethreutini}

Genus Eudemis HüBNER, [1825]

Eudemis profundana ([DENIS \& SCHIFFERMÜLLER], 1775)

\section{Specimens examined:}

Azerbaijan: Lenkeran District, Hirkan National Park, 25 May 2003, Q. castaneifolia, 3 우 우 Lenkeran District, 9 June 2004, Q. castaneifolia, $2 \sigma^{\top} \sigma^{\top}$.

Caterpillars damage $Q$. castaneifolia.

\section{Genus Hedya HüBnER, [1825]}

\section{Hedya nubiferana HAWORTH, [1811]}

\section{Specimens examined:}

Azerbaijan: Sheki District, Markhal area, 22 April 1995, Quercus sp., 1 \%; Sheki District, 11 May 1995, Armeniaca vulgaris, 1 ㅇ ; Baku city, 24 May 1995, Malus sp., 1 ㅇ; 24 May 1995, A. vulgaris, 2 ơ $^{\star}$; Sheki city, 28 May 1995, 2 ㅇ + ; Baku city, 29 May 1995, Prunus domestica, 1 ơ; Astara District, Tengerud v., 5 May 1997, Cydonia sp., 1 ; ; Astara District, Archivan v., 7 May 1998, Malus sp., 1 o $^{\star}$; Astara District, Serek v., 14 May 1998, Malus sp., 1 우.

Caterpillars and pupae were collected in nature. This species damages trees and bushes in the family Rosaceae. Of the five recorded hosts, Malus sp. and A. vulgaris were preferred (Table 1). 
This species overwinters as an early instar larva. Overwintering caterpillars hatch in the second week of April and feed on buds; they later attack leaves. Pupation occurs at the end of April and early May. Females lay about 150 eggs on leaves or occasionally on fruit, either or in groups of $2-8$. There is one generation annually.

\section{Tribe Eucosmini}

\section{Genus Spilonota STEPHENS, 1829}

Spilonota ocellana ([DENIS \& SCHIFFERMÜLLER], 1775)

Specimens examined:

Azerbaijan: Absheron penins., Merdekan sett.: 20 May 1995, Malus sp., 1 ; 30 May 1995, Malus sp., 1 \% ; Lenkeran District, Hirkan National Park, 29 April 2002, Q. castaneifolia, 1 ㅇ․

We collected caterpillars in nature. This species overwinters as a caterpillar starting in SeptemberOctober. Bud opening serves as the phenological signal for caterpillars to emerge in the spring. Early instars damage buds, and later instars feed on young leaves. Pupation takes place within the rolled leaves. Adults appear in June-July.

\section{Genus Epinotia HüBNER, [1825]}

Epinotia demarniana (FISCHER VON RÖSLERSTAMM, 1840)

Specimens examined:

Azerbaijan: Lenkeran District, Hirkan National Park, 1 June 2001, Alnus barbata, 1 \%; Lenkeran District, Hirkan National Park, 1 June 2001, A. barbata, 1 ․

\section{Genus Gypsonoma MYricK, 1895 Gypsonoma sp.}

Specimens examined:

Azerbaijan: Absheron, Merdekan, 22 June 1996, Populus sp., 4 우 우.

\section{Genus Notocelia HüBNER, [1825]}

\section{Notocelia uddmanniana (LINNAEUS, 1758)}

Specimens examined:

Azerbaijan: Lenkeran District, Hirkan National Park, 1 June 2001, Rubus sp., $20^{\star} \sigma^{\star}$.

Caterpillars feed on raspberry, strawberry, rose, and dog-rose, joining the leaves of the host by silk into a friable ball in which there may be 2-3 caterpillars. Adults appear in June-July. 


\section{Tribe Grapholitini}

\section{Genus Cydia HüBNER, [1825]}

Cydia pomonella (LinnaEus, 1758)

\section{Specimens examined:}

Azerbaijan: Astara District, Archivan v., 25 April 1995, Malus sp., 1 o'; Sheki District, Dodu v., 2 May 1995, Malus sp., 1 \%; Baku city, 14 May 1995, A. vulgaris, $10^{*}$; Astara District, Archivan v., 29 September 1995, Malus sp., 1 \% ; Baku city, 30 July 1996, Malus sp., 1 \%; Astara District, Archivan v., 14 May 1997, Q. castaneifolia, 1 ㅇ.

Cydia pomonella is oligophagous; we recorded it from three plant species, with Malus sp. the primary host (Table 1). There are two generations per year. Females lay eggs on the underside of the leaf. Productivity of the female is 60-120 eggs. Newly hatched caterpillars penetrate into the pulp of the fruit and make a chamberlike cavity. The following instars feed in the seed cavity. The fourth instar completes feeding and leaves the fruit to pupate. Moths are active at dusk.

\section{Discussion}

\section{Analysis of the species composition of the leaf rollers}

During studies conducted from 1994-2004 we documented 16 species of leaf- rollers belonging to 14 genera. They belong to two subfamilies: Tortricinae ( 9 species in 7 genera) and Olethreutinae (7 species in 7 genera). Tortrix viridana represented $46.0 \%$ of the total specimens,

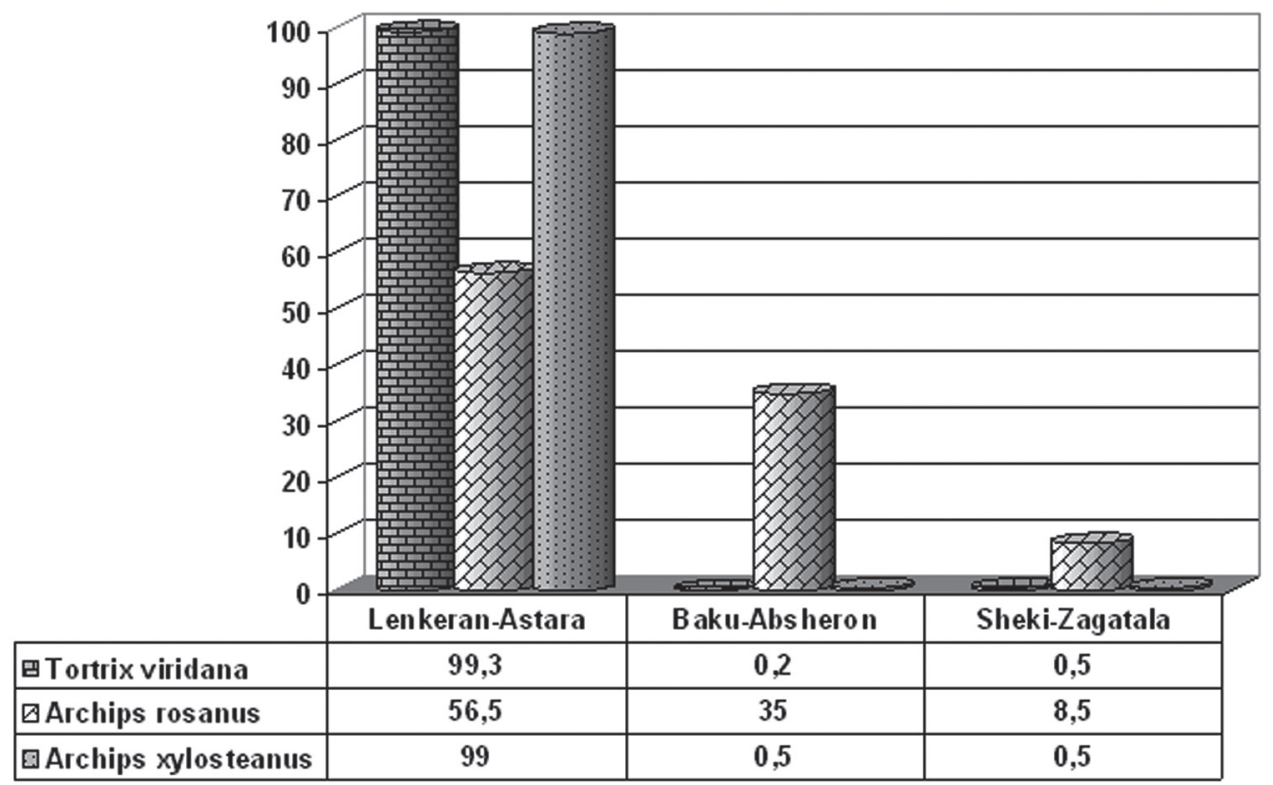

Fig. 2: Distribution of Tortrix viridana, Archips rosanus and Archips xylosteanus in different regions of Azerbaijan. 
Archips rosanus L. $28.0 \%$, and Archips xylosteanus L. $20.2 \%$. Four species were newly recorded for Azerbaijan (Table 1): Ptycholoma lecheana, Cacoecimorpha pronubana, Eudemis profundana, and Epinotia demarniana.

Fourteen species of leaf-rollers (87.5 \%) were collected in the Lenkoran-Astara, 9 species (56.2 \%) in the Baku-Absheron, and 5 species (33.3\%) in the Sheki-Zaqatala. Five species were found in all three regions. The three most abundant species during the survey (i.e., Tortrix viridana, Archips rosanus, and Achips xylosteanus) were most numerous in Lenkoran-Astara (Fig. 2). Figure 2 shows the share of all collected samples in Lenkaran-Astara, Baku-Absheron and Sheki-Zagatala regions during the studied period. For example, totally 428 samples of $T$. viridana were collected. From them 425 (99,3\%) distributed in Lenkoran-Astara region, 1 (0,2 \%) in the Baku-Absheron and $2(0,5 \%)$ in the Sheki-Zagatala region.

Archips crataeganus (Hüвn.), Ptychotoma lecheana (L.), Aleimma loeflingiana (L.) were the least common species, each representing about $0.1 \%$ of the total specimens collected.

Two species (P. lecheana, Gypsonoma sp.) were recorded only in the Baku-Absheron, and 7 species (E.profundana, A. loeflingeana, C. forscaleana, P. cerasana, E. demardiana, N. uddmanniana, A. crataegana) only in Lenkoran.

\section{Host Associations}

Species composition varied from region to region, with many leaf-rollers strongly associated with specific plant species.

Research in the Sheki-Zagatala region was conducted in 1995 where leaf-rollers were recored primarily on apple, apricot, plum, and oak. Approximately $56 \%$ of damage was to apple tree and $28 \%$ to oak. Other trees suffered from leaf-rollers totally $2-14 \%$.

Research in the Baku-Absheron peninsular was conducted during 1995-1997, 1999-2001, 2003-2004. Apricot (26.75\%), indigo (14.65\%), apple (12.1 \%) suffered serious damage from leaf-rollers. Ash-tree, Populus sp., and U. campestris suffered 5.73-8.92\% damage. Other plants suffered considerable less, from $0.64-4.46 \%$.

Research in the Lenkoran region was conducted in 1994-1998, 2001-2004, and thirteen species of leaf-rollers were documented. They were associated with 21 plant species. Damage caused by leaf-rollers was as follows: Quercus castaneifolia whose damage constituted $51.4 \%$ of all the damage caused; P. persica (11.3\%), Z. caprinifolia (7.5\%), U. suberosa (6.1\%). Other plants suffered to a lesser degree (0.12 to $3.47 \%$ ) (Maharramova, 2008).

In all areas studied, three species of leaf-rollers (A. rosanus, A. xylosteanus, and T. viridana) had a wide range of food plants. A. rosanus was documented from 26 species of plants, A. xylosteanus from 12, and T. viridana from 10. T. viridana was the most abundant species in 2000-2002 in the Lenkoran region (in the territory of the Hyrkan National Park, as well), causing serious damage to more than 10 plant species. T. viridana, a heat-loving, xerophilous species (Zerova et al., 1989), was recorded mainly at the flanks and edges of forest causing up to $80 \%$ damage to host plants. During outbreaks it seriously damaged relict and endemic trees in the Hyrcan National Park including $P$. persica and $Z$. carpinifolia which are representatives of the tertiary and the quaternary periods. 


\section{Yearly distribution}

Leaf-rollers were most numerous in 2001, with nine species were recorded (Table 1): eight from the Lenkoran-Astara region and one from the Baku-Absheron region. Five of the species from the Lenkoran-Astara region were uncommon (represented by less than 9 individuals): A. crataegana, C. forskaleana, Spilonota ocellana, E. demardiana, and N. uddmanniana. The lowest year in terms of species richness was 1994 with only two species recorded. Five species were recorded in 1996, with one (i.e., T. viridana) from the Lenkoran-Astara region and 4 (A.rosanus, A.xylosteanus, Gypsonoma sp., Cydia pomonella) from the Baku-Absheron region. In 1997, 2003 and 2004 only four species were recorded, all of which were recorded in Lenkoran-Astara region, with A. rosanus and T. viridana also recorded from the BakuAbsheron. In 1998-2002 three species were recorded (one species in Baku-Absheron two in Lenkoran-Astara region); in 1994 two species were recorded (in Lenkoran-Astara region). In 1999 only one species was recorded (in Lenkoran-Astara region). A. rosanus and T. viridana were documented every year in all studied period.

\section{Acknowledgments}

I am grateful to Dr. Shargiya Abdullayeva (Entomological department of the Institute of Zoology of the NAS of Azerbaijan) and Dr. Mustafa Ozdemir (Plant protection and taxonomy museum, Ankara, Turkey) for determination of tortricids, to Dr. Ilhama Kerimova (Entomological department of the Institute of Zoology of the NAS of Azerbaijan) for translation and to Dr. JoHn Brown (National Museum of Natural History, Washington, DC, USA) for edition of manuscript.

\section{References}

Abdullayeva, S. Y. 1988: About of the fauna of leaf rollers (Lepidoptera, Tortricidae) in east of Azerbaijan. - Az AS informations, Biol. Res., series, N4: 69-74. (in Azerb.)

Abdullayeva, S. Y. 1990: About of the fauna of leaf rollers (Lepidoptera, Tortricidae) in east of Azerbaijan. - Az AS informations, Biol. Res., series, N3: 70-73. (in Azerb.)

Akhundova-Tuayeva, L. M. 1960: K izucheniyu cheshuekrilikh vredyashix drevesno-kustarnikovim porodam v Lenkoranskoy zone. - Uch. zap. AGU named S. M. Kirova, N1. (in Russian)

Bogachev, A. V. 1951: Listovertki - Tortricidae. - In book: Jivotniy Mir Azerbaijana, Baku, Pub. AzCCR, 1951, 382-383. (in Russian)

Brown, J. W. 2005: World Catalogue of Insects. Volume 5. Tortricidae (Lepidoptera). - Apollo Books, 741 pp. (in English)

Fasulati, K. K. 1971: Poleviye izucheniye na zemnikh bezpozvonochnikh. - Izd. Visshaya Shkola. Moskva, 423 pp. (in Russian)

Lozovoy, D. I. 1965: Vredniye nasekomiye parkovikh i lesoparkovikh nasajdeniy Gruzii. - Tbilisi: 272 pp. (in Russian)

Maharramova, S. M. 2003: The role of parasitoid complex in Archips rosana L. (Lepidoptera, Tortricidae) number management. - First Congress of Azerbaijan Society of Zoologists. Elm, Baku 2003: pp. 230-236. (in Azerb.)

Maharramova, S. M. 2006: Leaf-rollers (Lepidoptera: Tortricidae) damaging to fruit-wood cultures of the Lenkoran region. - Proceedings of the Azerbaijan Institute of Zoology, Vol. XXVIII: Baku, Elm: pp. 542-551. (in Azerb.)

Maharramova, S. M. 2008: Factor effecting on outbreak of green leaf roller (Tortrix viridana L., Tortricidae). - Proceedings of the Azerbaijan society of Zoologists, Volume 1, Baku, Elm: pp. 291-297. (in Azerb.) 
Rayxxolf-Rim, X. 2002: Babochki. - Moscow, Astrel. (in Russian)

Voronsov, A. I. 1967: Lesnaya entomologia. M. - Visshaya shkola. (in Russian)

Zerova, M. D.; Kotenko, A. G.; Seregina, L. Y. \& Tolkanits, V. I. 1989: Entomofagi zelenoy dubovoy listovertki i neparnogo shelkopryada yugo-zapada evropeyskoy chasti SSSR. - Kiev: 200 pp. (in Russian)

Author's address:

Sheyda Maharramova

Institute of Zoology

National Academy of Sciences

of Azerbaijan Republic, Az1073

pr. 1128, bl. 504, Baku, Azerbaijan

sheyda@bakililar.az
Subject editor:

Dr. W. NÄssIG 


\begin{tabular}{|c|c|c|c|c|c|c|c|c|c|c|c|c|c|}
\hline \multirow{2}{*}{\multicolumn{2}{|c|}{ 氞 }} & $0^{\circ}$ & $\hat{o}$ & $\stackrel{\infty}{\sim}$ & $\overrightarrow{0}$ & ָ̃. & $\overrightarrow{0}$ & กֶ. & $\overrightarrow{0}$ & $\begin{array}{l}\text { ô } \\
\text { i }\end{array}$ & $\hat{o}$ & $\tilde{n}$ & $\stackrel{\sim}{-}$ \\
\hline & & $\begin{array}{l}\text { (suəu!̣ads u!) } \\
\text { s[enp!n!pu }\end{array}$ & $\infty$ & : & - & $\stackrel{\infty}{\stackrel{\infty}{\sim}}$ & - & $\sim$ & - & $\stackrel{\infty}{\underset{\forall}{\sim}}$ & $\infty$ & $n$ & $=$ \\
\hline \multirow{3}{*}{ 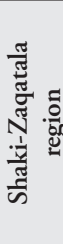 } & \multicolumn{2}{|c|}{ 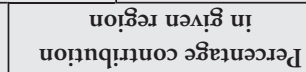 } & & $\stackrel{n}{n}$ & & $\tilde{o}$ & & & & $\tilde{o}$ & & & గị. \\
\hline & \multirow{2}{*}{ 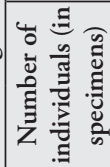 } & ฮేّ & & กี & & - & & & & $\sim$ & & & $\checkmark$ \\
\hline & & $\check{\sigma}$ & & สิ & & - & & & & $N$ & & & $\checkmark$ \\
\hline \multirow{10}{*}{ 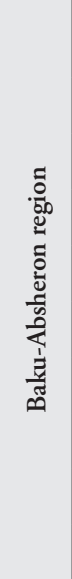 } & \multicolumn{2}{|c|}{ 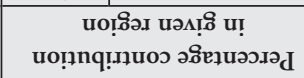 } & & $\hat{n}$ & & $\tilde{o}$ & @ & in & & กֶ. & & & $\begin{array}{l}\text { ঠి. } \\
\text { }\end{array}$ \\
\hline & \multirow{9}{*}{ 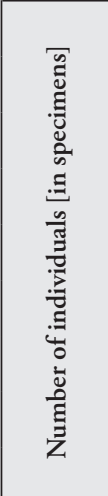 } & [ำ] & & $\bar{\sigma}$ & & - & - & - & & - & & & $\checkmark$ \\
\hline & & $\mp 00 z$ & & 6 & & & & & & & & & \\
\hline & & $\varepsilon 00 z$ & & - & & & & & & & & & \\
\hline & & I00Z & & & & & - & & & & & & \\
\hline & & 666I & & - & & & & & & & & & \\
\hline & & $866 \mathrm{I}$ & & & & & & - & & & & & \\
\hline & & $\angle 66 \mathrm{I}$ & & $\tilde{n}$ & & & & & & - & & & \\
\hline & & 966I & & $\approx$ & & - & & & & & & & \\
\hline & & S66I & & $\ddot{\sim}$ & & & & & & & & & $\forall$ \\
\hline \multirow{12}{*}{ 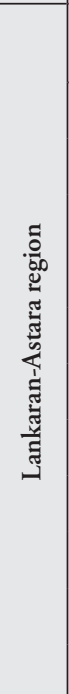 } & \multicolumn{2}{|c|}{ 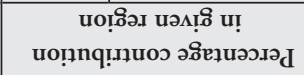 } & 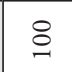 & $\underset{n}{n}$ & 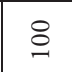 & बे & & in & 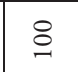 & $\stackrel{n}{\alpha}$ & $\stackrel{0}{0}$ & $\stackrel{8}{ }$ & $\stackrel{n}{\hat{N}}$ \\
\hline & \multirow{11}{*}{ 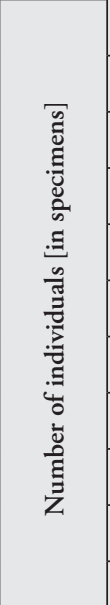 } & [ำ10] & $\infty$ & $\underset{ \pm}{\nsubseteq}$ & - & $\stackrel{\infty}{\infty}$ & & - & - & $\approx$ & $\infty$ & $n$ & $m$ \\
\hline & & $\mp 00 z$ & & ㄱ. & & $a$ & & & & $\simeq$ & & $\sim$ & \\
\hline & & $\varepsilon 00 z$ & & & & & & - & - & & & $m$ & \\
\hline & & $z 00 z$ & & $\sim$ & & $\stackrel{m}{m}$ & & & & - & & & \\
\hline & & I00Z & & $\stackrel{n}{0}$ & - & $\exists$ & & & & $\tilde{\lambda}$ & $\infty$ & & \\
\hline & & 666I & & - & & & & & & & & & \\
\hline & & $866 \mathrm{I}$ & & & & & & & & - & & & N \\
\hline & & $\angle 66 \mathrm{I}$ & & 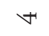 & & & & & & $\beth$ & & & - \\
\hline & & 966I & & & & & & & & $n$ & & & \\
\hline & & S66I & $\infty$ & $\stackrel{0}{-1}$ & & & & & & $a$ & & & \\
\hline & & $\lessgtr 66 \mathrm{I}$ & & - & & & & & & $\bullet$ & & & \\
\hline & & 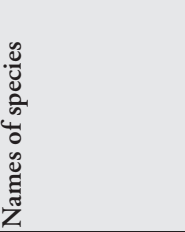 & 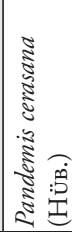 & 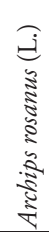 & 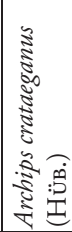 & 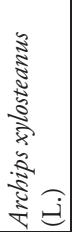 & 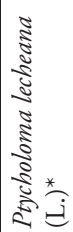 & 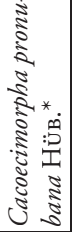 & 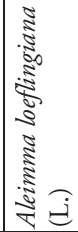 & 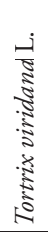 & 竎 & 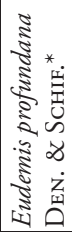 & 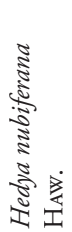 \\
\hline
\end{tabular}


Beitr. Ent. 61 (2011) 1

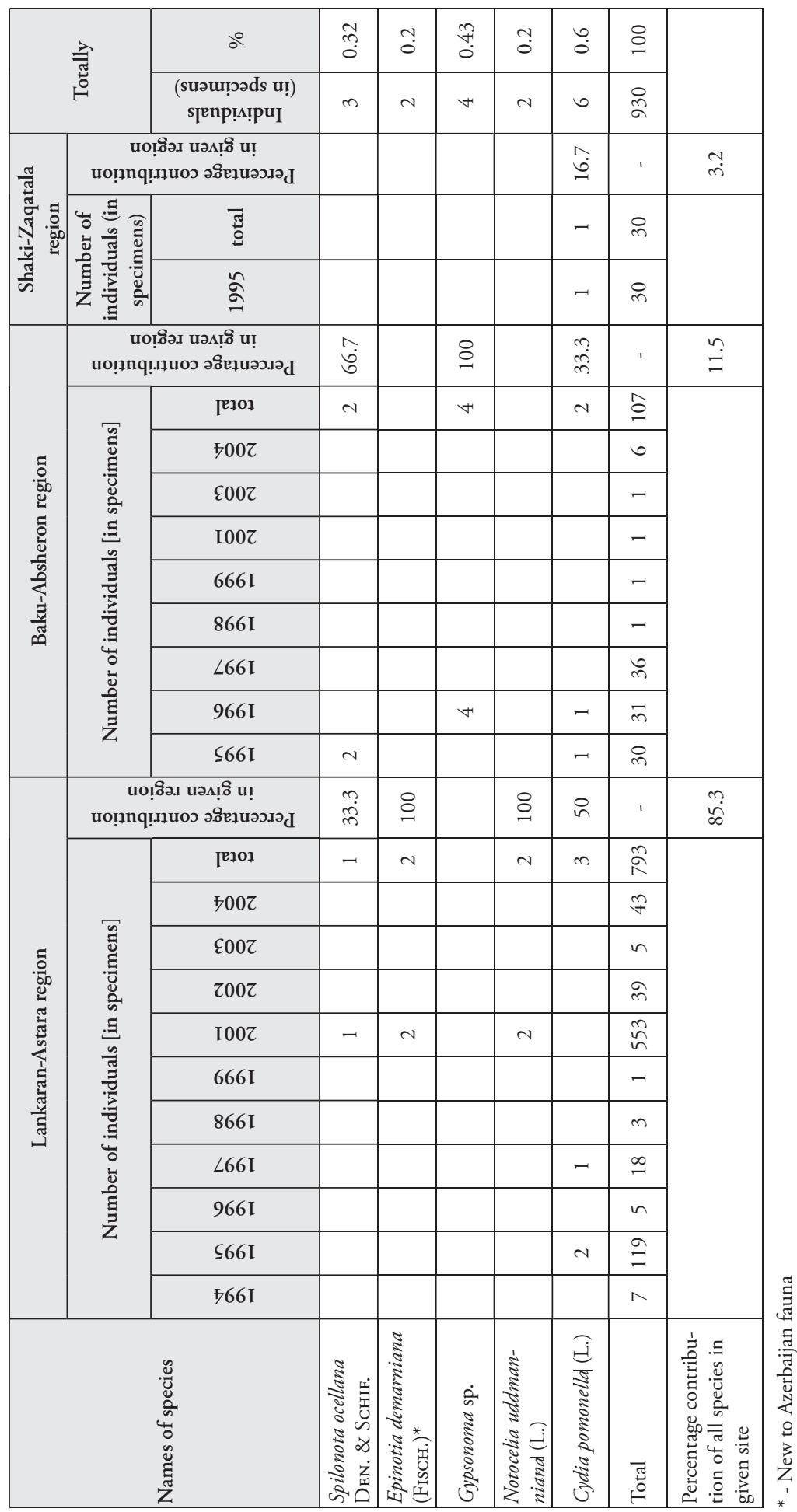


Tab. 2: Food connection of leaf rollers (1994-2004) in Azerbaijan.

\begin{tabular}{|c|c|c|c|c|}
\hline Leaf rollers & $\begin{array}{l}\text { Leaf rollers } \\
\text { recording years }\end{array}$ & $\begin{array}{l}\text { Number of } \\
\text { host plants }\end{array}$ & $\begin{array}{l}\text { Host plants \& number of leaf roller } \\
\text { samples on them }\end{array}$ & $\begin{array}{l}\text { Preferred host } \\
\text { plants of leaf } \\
\text { rollers }\end{array}$ \\
\hline Pandemis cerasana & 1995 & 2 & $\begin{array}{l}\text { Crataegus sp. - 2, } \\
\text { Malus sp. - } 6\end{array}$ & Malus sp. \\
\hline Archips rosanus & $\begin{array}{l}\text { 1994, 1995, } \\
1996,1997 \\
1999,2001 \\
2002,2003 \\
2004\end{array}$ & 26 & $\begin{array}{l}\text { Q. castaneifolia - 51, Malus sp. - 36, } \\
\text { A. vulgaris - 35, P. persica - 20, Rubus L. } \\
\text { - 18, A. fruticosa - 18, Crataegus sp. } \\
\text { - 9, Fraximus sp. - 7, Z. carpinifolia } \\
\text { - 4, Mespilus Z - 2, C. caucasica - 3, } \\
\text { A. barbata-7, A. hyrcanum - 1, R. pseudo- } \\
\text { acacia - 3, G. caspia - 4, P. digitifolia - 2, } \\
\text { Ligustrum sp. - 8, S. Kusnetzowii - 9, } \\
\text { Colutea sp. - 2, Tilia sp. - 4, M. aurantica } \\
\text { - 1, P. granatum L. - 1, Cydonia sp. - 8, } \\
\text { P. domestica - 1, U. suberosa - 2 }\end{array}$ & $\begin{array}{l}\text { Q. castaneifolia } \\
\text { Malus } \mathrm{sp} \text {. } \\
\text { A. vulgaris } \\
\text { P. persica } \\
\text { Rubus } \text { L. } \\
\text { A. fruticosa }\end{array}$ \\
\hline Archips crataegana & 2001 & 1 & Rubus sp. -1 & \\
\hline Archips xylosteanus & $\begin{array}{l}\text { 1995, 1996, } \\
2001,2002, \\
2004\end{array}$ & 10 & $\begin{array}{l}\text { Q. castaneifolia - 119, P. persica - 27, } \\
\text { C. caucasica - 11, P. hyrcana - 9, Z. carpi- } \\
\text { nifolia - 13, Mespilus Z. - 4, Malus sp. - 1, } \\
\text { Rubus L. - 1, A. vulgaris - 1, A. subcordata } \\
-1\end{array}$ & $\begin{array}{l}\text { Q. castaneifolia } \\
\text { P. persica } \\
\text { Z. carpinifolia } \\
\text { C. caucasica }\end{array}$ \\
\hline Ptycholoma lecheana & 2001 & 1 & Q. castaneifolia -1 & \\
\hline $\begin{array}{l}\text { Cacoecimorphapronu- } \\
\text { bana }\end{array}$ & $\begin{array}{l}1997 \\
2003\end{array}$ & 2 & $\begin{array}{l}\text { Laurus sp. - 1, } \\
\text { Ligustrum sp. - } 1\end{array}$ & \\
\hline $\begin{array}{l}\text { Ailemma loeflingia- } \\
\text { num }\end{array}$ & 2003 & 1 & Q. castaneifolia - 1 & \\
\hline Tortrix viridana & $\begin{array}{l}\text { 1994, 1995, } \\
\text { 1996, 1997, } \\
\text { 1998, 2001, } \\
2002,2004\end{array}$ & 12 & $\begin{array}{l}\text { Quercus sp. - 2, } \\
\text { Q. castaneifolia - 251, Tilia sp. - 3, Z. car- } \\
\text { pinifolia - 30, Mespilus sp. - 11, } \\
\text { U. suberosa-50, P. persica }-40 \text {, Cydonia sp. } \\
\text { - 9, Crataegus sp. - 10, } \\
\text { C. caucasica - 12, } \\
\text { P. hyrcana - 6, A. barbata - } 3\end{array}$ & $\begin{array}{l}\text { Q. castaneifolia } \\
\text { U. suberosa } \\
\text { P. persica } \\
\text { Z. carpinifolia }\end{array}$ \\
\hline Croesia forskaleana & 2001 & 1 & A. hyrcanum -8 & A. hyrcanum \\
\hline Eudemis profundana & 2003, 2004 & 1 & Q. castaneifolia - 5 & Q. castaneifolia \\
\hline Hedya nubiferana & $\begin{array}{l}1995 \\
1998 \\
1997 \\
\end{array}$ & 5 & $\begin{array}{l}\text { Cydonia sp. - 1, Malus sp. - 3, A. vulgaris } \\
-5, \text { P. domestica - 1, Quercus sp. - } 1\end{array}$ & $\begin{array}{l}\text { Malus sp., } \\
\text { A. vulgaris }\end{array}$ \\
\hline Spilonota ocellana & 1995,2002 & 2 & Malus sp. - 2, Q. castaneifolia - 1 & Malus sp. \\
\hline Epinotia demarniana & 2001 & 1 & A. barbata -2 & A. barbata \\
\hline Gypsonoma sp. & 1996 & 1 & Populus sp. -4 & Populus sp. \\
\hline $\begin{array}{l}\text { Notocelia uddmanni- } \\
\text { ana }\end{array}$ & 2001 & 1 & Rubus L. - 2 & \\
\hline Cydia pomonella & 1995, 1996, 1997 & 3 & $\begin{array}{l}\text { Malus sp. - 4, Q. castaneifolia - 1, A. vul- } \\
\text { garis - } 1\end{array}$ & Malus sp. \\
\hline
\end{tabular}

